\title{
NEW FINDINGS OF FOSSIL LARGE MAMMAL REMAINS IN THE PENIOS VALLEY (AREA OF LARISSA, THESSALY, GREECE)*
}

\section{A. ATHANASSIOU ${ }^{1}$}

\section{ABSTRACT}

Fossil large mammal remains that come from the Penios valley, Thessaly, are described and compared to already known specimens. The studied material includes two elephant mandibles, tusk fragments and limb bones, as well as a part of a large bovid skull. On the basis of morphology and biometry the sample is taxonomically referred to the species Elephas antiquus and Bos primigenius. An Upper Pleistocene age is assumed.

\section{IYNO世H}

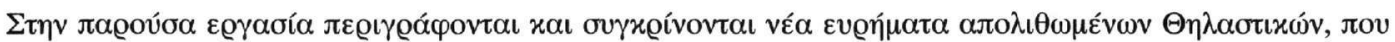

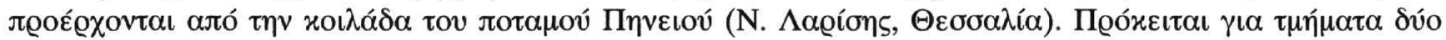

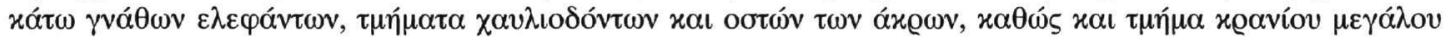

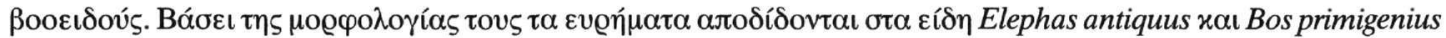

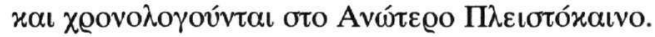

KEY WORDS: Greece, Thessaly, Penios valley, Pleistocene, Proboscidea, Elephas antiquus, Artiodactyla, Bos primigenius

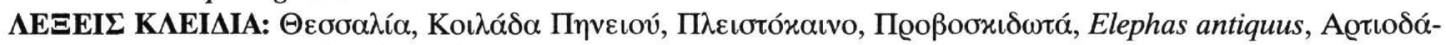
$\varkappa \tau v \lambda \alpha$, Bos primigenius

\section{INTRODUCTION}

The material of the present study comprises some odontological and osteological elephant remains, as well as a specimen (partial skull) of a big bovid. It comes from an excavation carried out by amateurs in the riverbed of Penios, during the very dry summer of 1988 , when the riverbed was exposed. The excavation site is situated between the city of Larissa and the gorge of Kalamaki. Its approximate position is indicated in Fig. 1.

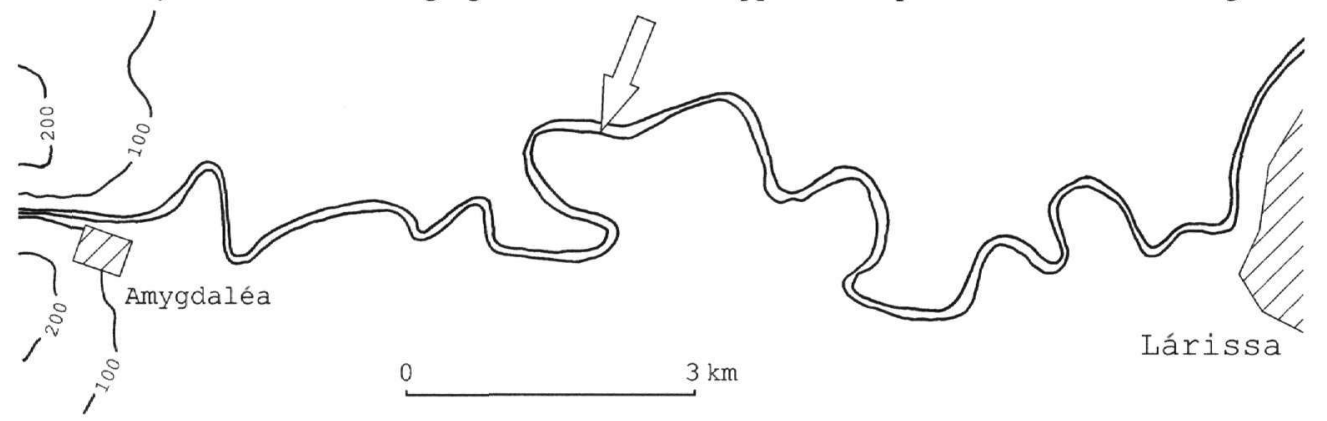

Fig. 1: Schematic map of the Penios valley area, between the city of Larissa and the gorge of Kalamaki. The arrow shows the approximate position of the fossil finds.

This area of the Penios valley is already known since many years for its fossil fauna, as well as for Palaeolithic artefacts (Milojerz et al., 1965; SCHNEIDER, 1968). Some other elephant remains found close to the mouth of the same river are reported by PARASKEVAIDIS (1977). The material under study was given by the excavators to the

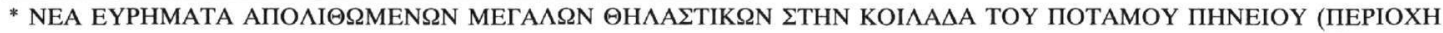
$\Lambda \mathrm{API} \Sigma \mathrm{H} \Sigma, \Theta \mathrm{E} \Sigma \Sigma \mathrm{A} \Lambda \mathrm{IA})$

1. University of Athens, Dept. of Historical Geology and Palaeontology, GR-15784 ATHENS aathan@cc.uoa.gr
} 
Museum of Geology and Palaeontology of the University of Athens and it currently belongs to its collections.

The locality is situated in the East Thessalian Plain, near to the area where Penios flows out of the Kalamaki gorge. The region is covered by alluvial fluvio-lacustrine sediments (silt, clay, sand and pebbles), which overlay marbles and crystalline limestones of the Pelagonian zone. The riverbanks are very steep, due to erosion, allowing the exposure of the lower fluvio-lacustrine strata during dry periods.

Fossil elephant remains, mainly of the species Mammuthus meridionalis (NESTI, 1825) and Elephas antiquus FALCONER \& CAUTLEY, 1845, are quite common in Greece as mainland or insular (endemic) forms ( $\triangle$ EPMITZAKH et al., 1982; Dermitzakis \& Theodorou, 1980; Doukas \& Athanassiou, in press).

In the present study the elephant remains are measured and described according to the methods proposed by Maglio (1973).

\section{SYSTEMATICS}

$\begin{array}{ll}\text { Order: } & \text { Proboscidea ILLIGER, 1811 } \\ \text { Suborder: } & \text { Elephantoidea OSBORN, 1921 } \\ \text { Family: } & \text { Elephantidae GrAy, 1821 } \\ \text { Subfamily: } & \text { Elephantinae GrAy, 1821 } \\ \text { Genus: } & \text { Elephas LINNAEUS, 1758 }\end{array}$

Elephas antiquus FALCONER \& CAUTLEY, 1845

(Fig. 2A, B)

Material - Tusk fragment $\left(\mathrm{I}^{2}\right)$ : $\Lambda \mathrm{A}-1$; tusk fragment $\left(\mathrm{I}^{2}\right)$ : $\Lambda \mathrm{A}-2$; tusk fragment $\left(\mathrm{I}^{2}\right): \Lambda \mathrm{A}-3$; part of mandible with part of right $\mathrm{M}_{3}: \Lambda \mathrm{A}-4$; mandible without teeth: $\Lambda \mathrm{A}-5$; distal part of right tibia: $\Lambda \mathrm{A}-6$.

Description - The preserved tusk fragments are very small (length $18-40 \mathrm{~cm}$ ), so their morphology (curvature, torsion etc.) is not known. All three fragments have small diameters, smaller than $14 \mathrm{~cm}$. The cross section of the retained parts is circular.

The two available mandibles are heavily built and relatively large. In $\Lambda \mathrm{A}-4$ only the right ramus is preserved, while the $\Lambda \mathrm{A}-5$ is almost intact but it lacks the teeth. The former is relatively higher in comparison to the latter. It has only one alveolus that accommodates the $\mathrm{M}_{3}$, which was the only functional tooth when the animal died. The $\Lambda \mathrm{A}-5$ has strong symphysis that forms proximally a short, narrow and pointed process, typical of the species. The existing alveoli show that this individual used the molars $\mathbf{M}_{2}$ and $\mathbf{M}_{3}$. The alveolus of $\mathbf{M}_{2}$ is very small, indicating that the molar was almost worn out and only its last plates were in use. The alveoli of $\mathrm{M}_{3}$ are very large to accommodate the third molars, which were in a rather early stage of wear.

The molar of the mandible $\Lambda \mathrm{A}-4$ is partly preserved, as its distal part is broken. The retained part consists of ten plates, of which the mesial are almost worn out. The last preserved distal plate is little worn, as the enamel forms islets on the occlusal surface. It is very possible that some more plates existed in the mesial part of the tooth, which have been worn out and discarded during the animal's life. The morphology of the alveolus shows that also at least 2-3 additional plates existed in the distal part of the molar. The tooth shows a lingual convexity, as well as a divergence of the plates towards the base, both being characters of the lower elephant molars (MAGLIO, 1973). The total length of the preserved part is $235 \mathrm{~mm}$. The maximal width of the molar is $101 \mathrm{~mm}$ and it is measured in the fifth plate (counting from the mesial end of the tooth). The maximal height is measured in the tenth plate (the most distal one) and it is $132 \mathrm{~mm}$. As the tenth plate is already worn, the total height of the third molar in life was surely greater. The retained height and width result to a hypsodonty index larger than 131. The enamel is relatively thick, $2.5-3.3 \mathrm{~mm}$, and intensively folded, especially in the median area of the plates. The plate frequency is relatively low; the mean value calculated from measurements in several areas of the crown (lingually, bucally, near the occlusal surface and near the base of the crown) is 4.1 (plates per $10 \mathrm{~cm}$ of molar length).

The tibia AA-6 is preserved only distally. The diaphysis is triangular in cross-section. The distal articulation is almost trapezoid in shape. The minimal diameters of the diaphysis (DAP and DT) are 85 and $108 \mathrm{~mm}$ respectively. The maximal dimensions of the distal end of the bone (DAP and DT) are 136 and $177 \mathrm{~mm}$ respectively.

Discussion - Two proboscidean species classified in the genus Elephas are known in the Middle-Upper Pleistocene of Eurasia: the European species E. antiquus (also attributed by older authors to the separate genus or subgenus Palaeoloxodon Matsumoto, 1924, due to the loxodont characters of its molars) and the Asian E. namadicus Falconer \& CAUTLEy, 1845. Some authors (as MAglio, 1973) consider the two species as synonyms, 
as they have many affinities in size and cranial and dental morphology to each other. In the case that the synonymy is accepted, all Middle and Upper Pleistocene Eurasian representatives of the genus Elephas should be named E. namadicus, as this name has priority over E. antiquus. However, most European authors still prefer to use the name E. antiquus, although most accept that the two species are hardly distinguishable between each other. Though considering the large variability of the elephants and the vast geographical distribution of the Eurasian Elephas, a possible distinction between the two alleged species could be difficult to see (see also PALOMBO, 1994; Shoshani \& TAssy, 1996: 360). Until a detailed comparative study of the European and Asian samples is made, it is better to keep both species names for the moment, and provisionally refer the European material to E. antiquus.

The morphology of the studied mandibles (with short and pointed chin), as well as the anatomical characters of the molar (inferred high plate number, folded enamel, hypsodonty), are typical for Elephas antiquus. The species is very common in the Middle and Upper Pleistocene of Europe and Greece in particular ( $\triangle$ EPMITZAKH et al., 1982; Dermitzakis \& ThFodorou, 1980; Doukas \& Athanassiou, in press).

General biometrical data for samples or individual finds of Elephas antiquus are given by several authors. The mandibles are comparable in size to the mandible 1960/27 from Megalopolis, described by MeLENTIS (1961) (Table 2). The relatively higher ramus of the studied specimens could be due to more advanced ontogenetical age.

The molar seems to be rather short and wide, compared to other known samples of the species (Table 1). The relatively small total length and low plate number are due to the post mortem breakage and loss of the posterior plates, as well as to the possible loss of some mesial ones during the life of the animal, because of wear. The total width is, however, very high, usually higher than the maximal values measured in most available samples (Table 1). Musi Nicolussi (1971) reports, however, an even higher value. The hypsodonty index (100 X height / width) is also very low, both because of the large total width and the low total height. The real total height of the molar could, however, be fairly higher, as the distal, i.e. less worn, plates are missing. The calculated lamellar frequency is very low, lower than that of any known sample, but comparable with the lowest value given by AGuirre EnRIQuez (1968-1969).

The dimensions of the tibia are small in comparison to the data given in the literature. TrevisAn (1954: 43) gives a distal DT measurement of $260 \mathrm{~mm}$. Melentis (1963: Tabelle 20) gives 218-241 mm for the same measurement and 160-181 mm for the distal DAP of tibias from Megalopolis. The author refers the corresponding specimens to Archidiskodon meridionalis, though Elephas antiquus is provenly present in this locality. The modern aspect of the fauna shows, however, that they could well belong to the latter species.

Table 1: Comparative dimensions of selected Elephas antiquus $M_{3}$ samples from several European localities.

\begin{tabular}{|c|c|c|c|c|c|c|c|c|c|c|}
\hline $\begin{array}{c}\text { Elephas antiquus } \\
\text { Lower } \\
\text { Third Molar }\end{array}$ & 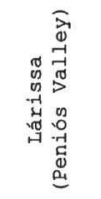 & 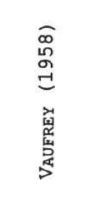 & 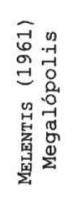 & 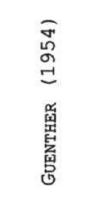 & 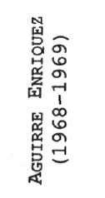 & 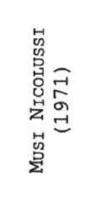 & 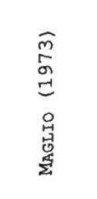 & 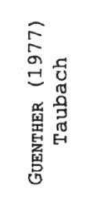 & 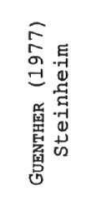 & 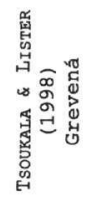 \\
\hline Total length & $235+$ & $275-480$ & 230 & $193-265$ & $237-411$ & $222-325$ & $232-339$ & $272-290$ & $255-330$ & 242 \\
\hline Total width & 101 & $62-92$ & 75 & $58-74$ & $58-97$ & $80-115$ & $50-88$ & $75-87$ & $63-95$ & 82.7 \\
\hline Total height & 132 & - & 153 & $137-140$ & $118-165$ & $120-210$ & $123-166$ & $142-160$ & $93-176$ & - \\
\hline Plate number & $10+$ & $15-20$ & 15 & 14 & $14-20$ & $8 \frac{17}{2}-17$ & $13-18$ & $13 \frac{1}{5}-16$ & $14-19$ & $14+$ \\
\hline Lamellar frequency & 4.1 & $4.5-6.0$ & 6.3 & $5.4-7.2$ & $4 \cdot 2-7.7^{1}$ & $5.0-6.0$ & $4.4-6.8$ & $5.6-6.7$ & $4.5-6.5$ & 6.0 \\
\hline Enamel thickness & $2.5-3.3$ & - & $2-2.5$ & $2.1-2.8$ & $2.2-3.3$ & $2 \cdot 7-5$ & $1.8-3.4$ & $2.4-3.0$ & $2.3-3 \cdot 5$ & $2 \cdot 3-3 \cdot 3$ \\
\hline Hypsodonty index & 131 & - & 204 & $185-241$ & $140-200$ & $140-213$ & $145-302$ & $171-215$ & - & - \\
\hline
\end{tabular}

${ }^{1}$ AGUIRRE ENRNQUEZ (1968-1969) uses the "functional lamellar frequency", which does not differ markedly from the plate frequency calculated according to the method of MAGLIO (1973). 
A
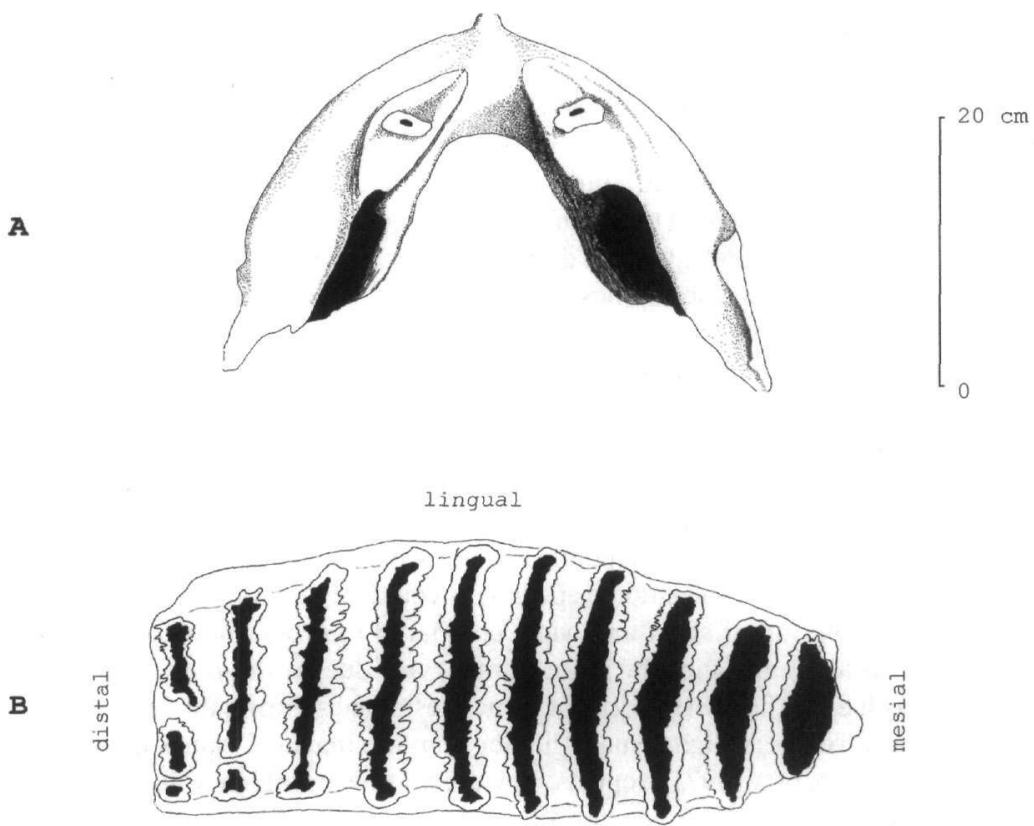

buccal
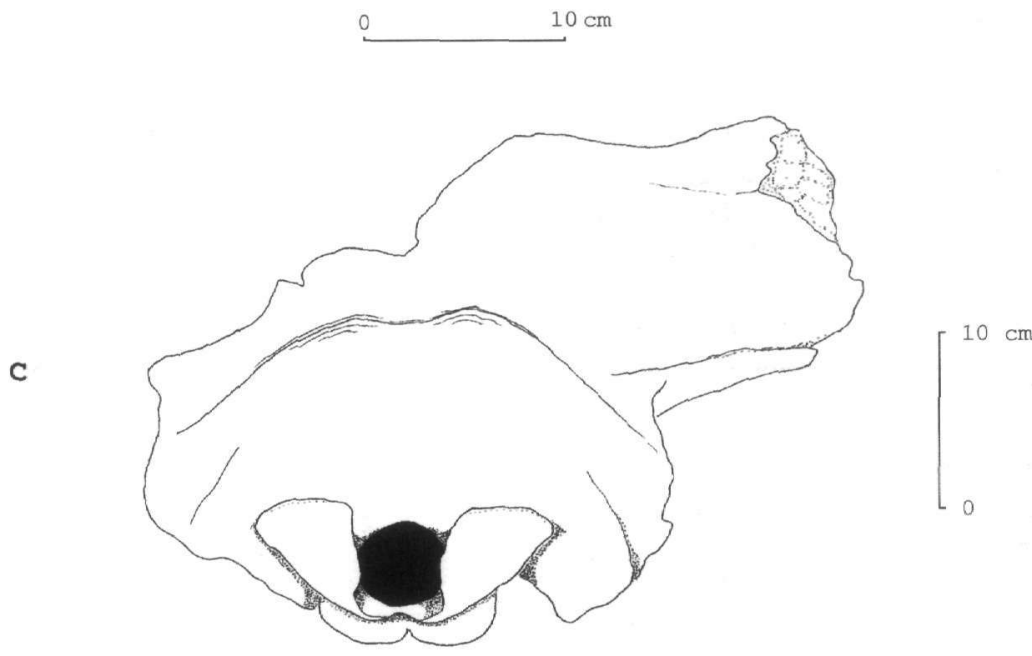

Fig. 2: Draft drawings of some of the specimens studied in this paper: A: Elephas antiquus FALCONER \& CAUTLEY, 1845, occlusal view of the mandible $1 A-5$; B: Elephas antiquus FALCONER \& CAUTLEY, 1845, occlusal view of the right lower third molar (specimen $1 A-4$ ); $C$ : Bos primigenius BoJANUS, 1827, occipital view of the cranium $\Lambda A-7$.

Many authors have distinguished several subspecies of Elephas antiquus in the past mainly based on the plate number, the lamellar frequency and the enamel thickness. OsBoRn (1942: 1217) divides the species in three subspecies, according to the number of plates in the last molars: E. a. antiquus, E. a. germanicus STEFANESCU, 1924 and E. a. italicus OsBorn, 1931 with $161 / 2-17,+18+$ and $18+$ plates in $M_{3}$ respectively. Taking into account the high morphological and biometricalvariety of the elephants, which is also intensified by marked sexual dimorphism (HAYNES, 1991), the absence of any statistical definition of these subspecies and the fragmentary state of the studied molar, a subspesific determination of the material is not possible. It is evident that many isolated and/or fragmentary finds that have been attributed to subspecies by several older authors (MELENTIS, 1961, 1963;

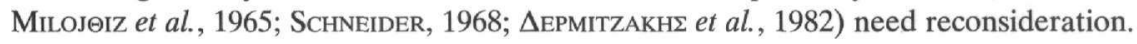




\begin{tabular}{|c|c|c|c|c|}
\hline $\begin{array}{c}\text { Elephas antiquus } \\
\text { Mandible }\end{array}$ & 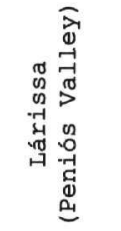 & 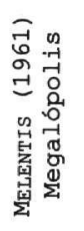 & 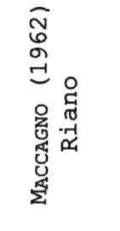 & 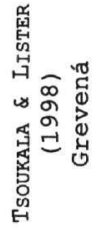 \\
\hline Total length & $>500$ & $>360$ & $540-700$ & - \\
\hline Total width & $>590$ & $>490$ & - & 630 \\
\hline Height of the horizontal ramus & $205-230$ & 185 & $158-250$ & - \\
\hline Length of the diastema & 134 & 140 & - & - \\
\hline
\end{tabular}

The wear stage of the one available molar $(\Lambda \mathrm{A}-4)$ can give some clues about the biological age of the individual it belonged to. According to observations on recent elephants (MAGLIO, 1973; HaYnEs, 1991) and considering the relatively larger size of the European Elephas antiquus that possibly implies a longer lifespan, the age of this animal could be about $45-50$ years. The mandible $\Lambda \mathrm{A}-5$ that seems to have had also a functional $\mathrm{M}_{2}$ could belong to a somewhat younger individual, about $35-40$ years old.

$\begin{array}{ll}\text { Order: } & \text { Artiodactyla Owen, } 1848 \\ \text { Family: } & \text { Bovidae Gray, 1821 } \\ \text { Subfamily: } & \text { Bovinae Gray, 1821 } \\ \text { Genus: } & \text { Bos LINNAEUS, 1758 }\end{array}$

\section{Bos primigenius BoJanUs, 1827}

(Fig. 2C)

Material - Cranium fragment (distal part): $\Lambda \mathrm{A}-7$.

Description - The cranium fragment $\Lambda \mathrm{A}-7$ preserves the occipital region and a small part of the cranial roof with the base of the left horn core. It is massively built and very big in dimensions. The horn core is directed laterally and its base has a horizontal position. Internally it is full of sinuses, as it is common in bovins. The horn core cross-section is elliptical, the antero-posterior diameter being smaller than the dorso-ventral one. The horn cores are very similar in morphology and dimensions (see Table 3 ) to the horn core 388 from Megalopolis, which is described by Melentis (1966).

Table 3: Comparative dimensions of Bos primigenius cranium.

\begin{tabular}{|c|c|c|}
\hline $\begin{array}{l}\text { Bos primigenius } \\
\text { Cranium }\end{array}$ & $\begin{array}{c}\text { Lárissa } \\
\text { (Peniós Valley) }\end{array}$ & $\begin{array}{l}\text { MELENTIS (1966) } \\
\text { Megalópolis }\end{array}$ \\
\hline Occipital breadth & 280 & - \\
\hline Total cranial height & $>300$ & - \\
\hline Breadth at the mastoid peoses & 245 & - \\
\hline Breadth of the occipital condyles & 157 & - \\
\hline Horn core DAP (base) & 105 & 87 \\
\hline Horn core dorsontral diameter (base) & 146 & 140 \\
\hline Horn core perimeter (base) & 390 & 375 \\
\hline
\end{tabular}




\section{BIOSTRATIGRAPHY-PALAEOECOLOGY}

The species Elephas antiquus characterises the European Middle and Late Pleistocene (MAGLio, 1973). The rather primitive aspect of the molar (reduced hypsodonty, low lamellar frequency) could indicate a rather old age. The species Bos primigenius is, however, confined in the Late Pleistocene (KuRTIN, 1968), being abundant during the postglacial. So, the available data point to a Late Pleistocene age for the studied specimens. A more detailed biochronology requires a larger sample of specimens and associated findings of other Mammals.

Elephas antiquus is considered as a forest species, adapted to temperate climate (KURTIN, 1968). Bos primigenius was probably a grassland or open woodland animal. This indicates dominance of mild climate and of a probably open woodland environment in the area.

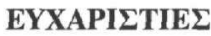

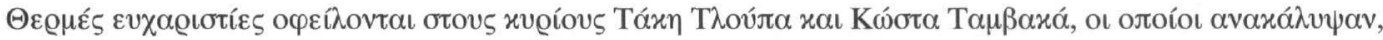

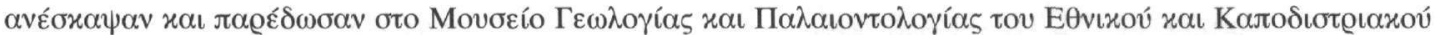

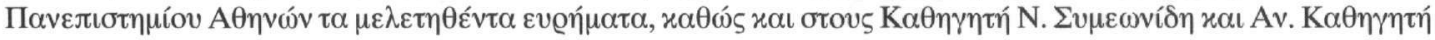

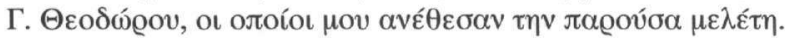

\section{REFERENCES}

AGUIRRE ENRIQUEZ, E. 1968-1969. Revisión sistemática de los Elephantidae por su morfología y morfometría dentaria. Estudios Geologicos XXIV (3-4), 109-167, XXV (1-2), 123-177, XXV (3-4), 317-367.

$\triangle$ EPMITZAKH $\Sigma$, M. $\Delta ., \Sigma$ YMESNI $\Delta H \Sigma$, N.K., BOER, L.E.M. DE \& SONDAAR, P.Y. 1982. H $E \xi \varepsilon \dot{\lambda} \iota \xi \eta \tau \omega v$

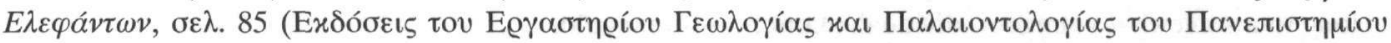

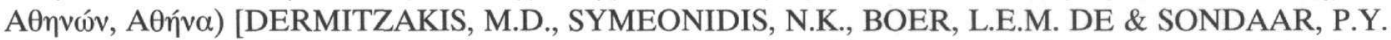
The evolution of the Elephants (Publications of the Laboratory of Geology and Palaeontology of the University of Athens Athens)].

DERMITZAKIS, M. \& THEODOROU, G. 1980. Map of the main fossiliferous localities of Proboscidea in Aegean area (Athens).

DOUKAS, C.S. \& ATHANASSIOU, A. (in press). Review of the Pliocene and Pleistocene Proboscidea (Mammalia) from Greece. $2^{\text {nd }}$ International Mammoth Conference, Rotterdam. Deinsea 8.

GUENTHER, E.W. 1954. Die diluvialen Elefantenz $\delta$ hne aus dem Nord-Ostsee-Kanal. Meyniana 2, $34-69$.

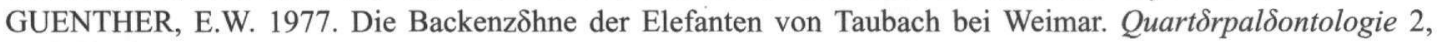
265-304.

HAYNES, G. 1991. Mammoths, Mastodonts and Elephants - biology, behavior and the fossil record, $413 \mathrm{pp}$. (Cambridge University Press, New York).

KURTIN, B. 1968. Pleistocene Mammals in Europe, 317 pp. (Weidenfeld and Nicolson, London).

MACCAGNO, A.M. 1962. Gli elefanti fossili di Riano (Roma). Geologica Romana I, 33-131.

MAGLIO, V.J. 1973. Origin and evolution of the Elephantidae. Transactions of the American Philosophical Society 63 (3), 1-126.

MELENTIS, J.K. 1961. Die Dentition der pleistozסnen Proboscidier des Beckens von Megalopolis im Peloponnes (Griechenland). Annales Giologiques des Pays Helliniques XII, 153-262.

MELENTIS, J.K. 1963. Die Osteologie der pleistozסnen Proboscidier des Beckens von Megalopolis im Peloponnes (Griechenland). Annales Grologiques des Pays Helliniques XIV, 1-107.

MELENTIS, J.K. 1966. Die Boviden des Jungpleistozסns des Beckens von Megalopolis im Peloponnes (Griechenland). Annales Giologiques des Pays Helliniques XVI, 446-472.

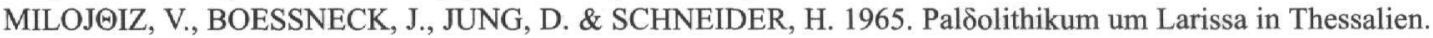

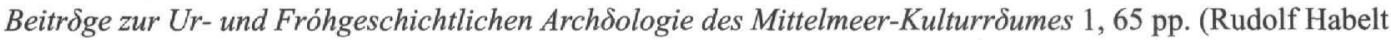
Verlag, Bonn).

OSBORN, H.F. 1936-1942. Proboscidea: a monograph of the discovery, evolution, migration and extinction of the Mastodonts and Elephants of the world. Vol. I, II, 1676 pp. (The American Museum Press, New York).

PALOMBO, M.R. 1994. Gli Elefanti del Pliocene superiore e del Pleistocene dell'Italia centrale peninsulare: alcune considerazioni. Studi Geologici Camerti vol. spec. 1994 (B), 447-457.

PARASKEVAIDIS, E. 1977. Sסugetierreste aus Griechenland. VIth Colloquium on the Geology of the Aegean Region, Proccedings III, 1143-1154.

SCHNEIDER, H. 1968. Zur quartorgeologischen Entwicklungsgeschichte Thessaliens (Griechenland). Beitroge zur

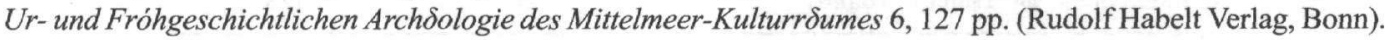


SHOSHANI, J. \& TASSY, P. (eds.) 1996. The Proboscidea - evolution and palaeoecology of Elephants and their relatives, 472 pp. (Oxford University Press, New York).

TREVISAN, L. 1954. Lo scheletro di Elephas antiquus italicus di Fonte Campanile Viterbo. Palaeontographia Italica XLIV, 1-78.

TSOUKALA, E. \& LISTER, A. 1998. Remains of straight-tusked elephant, Elephas (Palaeoloxodon) antiquus Falc. \& Caut., 1847 ESR-dated to oxygen isotope Stage 6 from Grevena (W. Macedonia, Greece). Bollettino della Societï Paleontologica Italiana 37 (1), 117-139.

VAUFREY, R. 1958. Proboscidea, ttude systımatique. In: PIVETEAU, J. Traitı de Pallontologie VI (2), 203-295. (Masson, Paris). 